\title{
The Limits of Natural Law: Liability for Wrongdoing in the Inleidinge
}

\section{Joe Sampson ${ }^{1}$}

\section{Introduction}

First published in 1631, Grotius's Inleidinge tot de Hollandsche rechtsgeleerdheid was authored during his time captive in Loevestein. ${ }^{2}$ In a letter to his children Grotius described the work, in somewhat apologetic terms, as a successor to Justinian's Institutes that sought to contain 'instructions in the law prevailing in Holland'. ${ }^{3}$ It purports to interweave those strands of Roman law still operative in seventeenth-century Holland with the relevant portions of local law, but in all respects it is a work constrained. With a poverty of resources available in captivity, both in terms of materials to consult and interlocutors with whom ideas might be developed, it is a work of an individual mind (and, to no small degree, an individual memory) that he thinks will be subject to additions before much longer. ${ }^{4}$ Ironically the absence of a full law library appears to have produced a more abstract and creative work than might otherwise have been the case. ${ }^{5}$ This has been noted in the remarkable terminological creativity employed within the treatise, laying the foundations for a Dutch legal language that would persist for centuries. ${ }^{6}$ The same creativity is even more forceful at a conceptual level. Without the ability to call upon sources, Grotius falls back upon his knowledge of natural law derived from Thomist sources, and in doing so sought to fit the doctrines of the law of Holland, local and civilian, within that framework.

The account of obligations arising from wrongdoing in Grotius's Inleidinge faithfully traces the contours of its natural law counterpart laid down in De Jure Belli ac Pacis. ${ }^{7}$ Of obligations in general he writes that the interplay between natural and local laws is far from harmonious, with local legal systems often articulating obligations in a manner unique to their own context. ${ }^{8}$ Consequently he claims to only refer to natural law in areas where there is insufficient certainty as to the state of the law of Holland. ${ }^{9}$ Nevertheless, when turning to obligations that arise inimically, natural law is given a central role in shaping the scope of the subject. Both in the range of wrongs covered by maleficium, and the consequences that attach to findings of responsibility, Grotius tracks his natural law account of delict closely (and in the case of the consequences, he expressly acknowledges the close parallel). ${ }^{10}$ By formulating

\footnotetext{
${ }^{1}$ Tutorial Fellow, Magdalen College Oxford and Associate Professor, Faculty of Law, University of Oxford. I am indebted to Mr Tim Lubbers and Professor Boudewijn Sirks for their assistance in identifying the local enactments to which Grotius referred, and to the reviewers for their helpful comments. Any errors remain my own.

${ }^{2}$ Nellen (tr. Grayson), Hugo Grotius: A Lifelong Struggle for Peace in Church and State 1583-1645 (Brill, 2014), 430.

${ }^{3}$ Lee, 'The Introduction to the Jurisprudence of Holland of Hugo Grotius' (1930) 16 Transactions of the Grotius Society 29, 35-36.

${ }^{4}$ Pre-empting the lengthy commentary of Groenewegen.

${ }^{5}$ It is notable that the most technical section of an institutional work, the law of actions, is omitted.

${ }^{6} 432-434$.

${ }^{7}$ Grotius (ed. Lee), The Jurisprudence of Holland (Clarendon, 1926) (hereafter 'Inleidinge'; translations into English taken from that edition); Grotius (eds Kanter-van Hettinga Tromp, Feenstra \& Persenaire), De Iure Belli ac Pacis Libri Tres in Quibis Ius Naturae et Gentium Item Iuris Publici Praecipua Explicantur (Scientia Verlag, 1993) (hereafter 'DJBAP')..

${ }^{8}$ Inleidinge, 3.1.21.

${ }^{9}$ Inleidinge, 3.1.22.

${ }^{10}$ The obligations that attach to liability, detailed in section 1, are both said to find their origins in natural law: Inleidinge, 3.32.7. The closeness of the generic local obligation to make restitution to its natural law counterpart
} 
the subject in this way, Grotius is presenting liability for wrongdoing in a way that is dissimilar to contemporary civilian treatments. ${ }^{11}$ Given its close correspondence to his treatment of the topic in De Jure Belli ac Pacis, it is apparent that Grotius is using natural law gleaned from Thomist sources, those same sources that fill the footnotes of his dedicated natural law scholarship, as a model for his exposition of the law of Holland, encompassing both civilian doctrine and existing local legislation. ${ }^{12}$

If reconciliation of natural law, civilian learning and the law of Holland was his project, it can only be considered a partial success. The natural law approach is fundamentally philosophical, built upon an Aristotelian conception of justice. To fit within this framework not only civilian doctrine but also those enactments unique to Holland would be no small feat, with each presenting its own difficulties. As laid down in De Jure Belli ac Pacis, Grotius's natural law analysis of liability for wrongdoing has three central features. The first, a direct consequence of its Aristotelian foundations, is a restorative remedy that seeks to maintain the equilibrium of wealth demanded by the twin notions of distributive and corrective justice. The second is a generalised analysis of wrongdoing based on the infringement of enumerated rights, rather than instantiated liability addressing particular patterns of prohibited conduct. The third is to attach consequences only in the presence of individual fault, and to resist any move towards strict liability. These three features will be used to explore Grotius's account of liability for wrongdoing in the law of Holland. Across the three, the same tensions will be encountered. Reconciliation of local and natural law is stymied not only by legislative enactments that simply cannot be assimilated into the natural law framework, but by the substantive and remedial expectations of his civilian-trained audience. The result is chimeric, a philosophical construct seeking to model liability in a principled fashion interspliced with alien strands of doctrine included for reasons of pragmatism or necessity. The nature of those strands that Grotius includes despite their incongruence with his broader approach to wrongdoing is informative. It is no surprise that legislative enactments could not be circumvented. It is a poor legal manual that ignores those laws that do not fit the author's legal ideals. More surprising are Grotius's other concessions. Across the range of liability for wrongdoing it is possible to see a handful of doctrinal inclusions which seem to have earned their place in the Inleidinge not for their own normative value or compatibility with Grotius's framework, but for their omnipresence in contemporary civilian accounts of delict. Their inclusion carries with it the sense of a pragmatic compromise. To convince his readership of the viability of his natural law based

is noted in Inleidinge, 3.32.20, with two points of departure: that local law can deem to be certain that which is in truth uncertain (alluding to the category of obligations quasi ex maleficio) and that at times the local obligation to restore can go beyond a strict interpretation of restoration.

${ }^{11}$ On the correspondence between Grotius on delict and contemporary civilian learning: Feenstra, Grotius' doctrine of liability for negligence: its origin and its influence in Civil Law countries until modern codifications' in Schrage (ed.), Negligence: The Comparative Legal History of the Law of Torts (Duncker \& Humblot, 2001); Sampson, The Historical Foundations of Grotius' Analysis of Delict (Brill, 2018), 229-244. The difference is striking when one takes a near-contemporary civilian treatise such as Zoesius, Commentarius ad Digestorum (Cologne, 1658), which due to its adherence to the titular structure of the Digest still approached delict in a fundamentally fragmentary manner.

${ }^{12}$ Grotius's account of liability for wrongdoing in De Jure Belli ac Pacis was particularly influenced by Lessius, De Iustitia et Iure Caeterisque Virtutibus Cardinalibus Libri Quatuor: Ad Secundam Secundae D. Thomae, a Quaest. 47, usque at Quaest. 171 (Paris, 1618), Martín de Azpilcueta (Navarrus), Enchiridion, sive Manuale Confessariorum et Poenitentium (Rome, 1588) and Domingo de Soto, De Iustitia et Iure Libri Decem (Salamanca, 1569). 
model of private law, it was necessary to show that it could cover the same ground as the existing legal framework, even at the cost of upsetting the theoretical purity of the model expounded by the Inleidinge.

\section{Section 1 - Remedies}

At the heart of Grotius's natural law account of liability for wrongdoing is a restorative remedy: restitutio. Adhering to the corrective justice framework of near-contemporary Thomist scholarship, the purpose behind this remedy was the smoothing out of inequalities caused by the wrongdoing of the defendant. ${ }^{13}$ It sought to do no more, and no less, than restoring the claimant to the position he was in prior to the wrong. ${ }^{14}$ Account could be taken of lost profits flowing from the wrong, but insofar as these were inherently uncertain, they were assessed at a lower value than concrete losses actually suffered. ${ }^{15}$ Restitutio was not the sole remedy envisaged in response to wrongdoing. That there ought to be penalties (poenae) is a matter of natural law, though the actual content of such penalties was devolved to individual local legal systems, leaving the duty to make restitutio as the only natural law obligation imposed in the wake of wrongdoing. ${ }^{16}$

At a taxonomical level Grotius's Inleidinge tracks the natural law approach closely. As in natural law, wrongdoing gives rise to two obligations: to suffer a penalty and to restore the inequality. ${ }^{17}$ The capacity of the state to impose punishments is justified in layers, by the natural law requirement that a penalty should be imposed, by the need for deterrence, and by the centralisation of coercive powers in central authorities after gravitating away from familial vengeance. ${ }^{18}$ The restoration of inequalities, weder-evening, is effectively a direct analogue for restitutio. The goal of re-equalisation, or restoring the balance of wealth demanded by justice, that lies behind restitutio's operation in De Jure Belli ac Pacis is expressed in the very language of weder-evening (re-equalisation). That weder-evening ought to be seen as restitutio is made clear through repeated references to the natural law origins of the remedy, such as in the claim that the obligation to restore arises out of the bare fact of wrongdoing, contrasted with the obligation to suffer a penalty which only arises upon imposition by an official. ${ }^{19}$

On the surface Grotius's localised considerations of delict follow their natural law equivalent closely, using weder-evening as the lynchpin concept in a similar fashion to the

\footnotetext{
${ }^{13}$ DJBAP, 2.17.1-3. On the relationship between Grotius and the thomist restitutio-centric model of private law: Feenstra, 'L'influence de la scolastique espagnole sur Grotius en droit privé' in Grossi (ed.), La seconda scolastica nella formazione del diritto private modern (Giuffré, 1973), 377-402; Jansen, Theologie, Philosophie und Jurisprudenz in der spätscholastischen Lehre von der Restitution (Mohr Siebeck, 2013), 176-187; Sampson, The Historical Foundations of Grotius' Analysis of Delict, 229-244. For an overview of the broader relationship between thomist (sc. neoscholastic) thought and early modern private law, see Decock, 'Law of property and obligations: neoscholastic thinking and beyond' in Pihlajamäki, Dubber and Godfrey (eds), The Oxford Handbook of European Legal History (Oxford, 2018).

${ }^{14}$ DJBAP, 2.17.1, 5.

${ }^{15}$ DJBAP, 2.17.5.

${ }^{16}$ DJBAP, 2.20.1. Penalties did not need to be directly proportionate with the harm done, a concession justifiable only if their content was not dictated by natural law: DJBAP, 2.20.32.

${ }^{17}$ Inleidinge, 3.32.7.

${ }^{18}$ Inleidinge, 3.32.7; in essence a truncated version of DJBAP, 2.20.

${ }^{19}$ Inleidinge, 3.32.9.
} 
central position of restitutio in De Jure Belli ac Pacis. But he quickly acknowledges that the overlap is not perfect, with the local weder-evening departing from the natural restitutio on occasion. ${ }^{20}$ However, the points at which such divergence occurs is unsystematic. It is typically the result of existing local legislation which, unlike accrued legal opinion, cannot be massaged so as to introduce a closer parallel to the idealised outcomes of natural law. Instead, the result is a patchwork wherein the natural law remedy is made to fit around awkward outcrops of prior enactments.

Grotius's first problem is showing how restitutio compares to conventional civilian remedies. This topic is dealt with most fully in a discussion of the obligation to restore 'on account of title to property'. ${ }^{21}$ The language adopted strongly resembles the restitutio ratione rei of Thomist private law doctrine, whereby the mere fact that the defendant possesses the claimant's property is sufficient to generate an obligation to restore it, regardless of fault. ${ }^{22}$ Within Thomist private law this is one of just two triggers for the restorative remedy restitutio, the other being restitutio ratione acceptionis which looks to how the defendant's conduct contributed to a state of inequality. Restitutio ratione rei is essentially a proprietary claim, requiring no justification beyond the possession of another's property, whereas restitutio ratione acceptionis as a personal claim requires some obligative rationale - whether contractual or delictual - for the remedy to be triggered. As such, it is the latter that dominates Thomist and Thomist-influenced accounts of delict, and characterises Grotius's account of restitutio in De Jure Belli ac Pacis. ${ }^{23}$

The label 'on account of title to property' is indicative of restitutio ratione rei, although to Grotius gives it a delictual twist given its location within the Inleidinge: 'reparation is also due... on account of possession, unless it be very clear that the possessor from whom anything is taken is not the owner, but someone else, as in this case the wrongdoer is bound by all lawful ways and means to assist the owner in regaining his own'. ${ }^{24}$ By including a reference to wrongdoing, Grotius appears to have in mind a scenario such as a thief (A) stealing property that his victim (B) had himself stolen from the true owner (C). Should the fact that B was himself a male fide possessor be obvious, then the current thief A is bound to do all he lawfully can to track down the true owner $\mathrm{C}$; otherwise his duty is to restore the thing to $\mathrm{B}$. This is effectively highlighting the possible tension between the two forms of restitutio. A owes the thing to B by virtue of his wrongful action (giving rise to restitutio ratione acceptionis) and to $\mathrm{C}$ by virtue of C's ownership of the thing (giving rise to restitutio ratione rei). As both claims relate to a single thing, one must go unsatisfied. Grotius tells us to prefer restitutio ratione rei where it is possible for A to track down $\mathrm{C}$. This solution effectively gives a sequence of priority to the two forms of restitutio, affording primacy to the in rem species of the remedy over its in personam form. This is slightly different from the civilian position, where there is no inherent tension between C's recovery of his property and possible claims addressing A's theftuous taking. The tension only arises as both dimensions of the claim are channelled through a single remedy. Moreover, there is a difference in the party on whom the analysis focuses: for civilians, the onus is on the owner (C) to bring a

\footnotetext{
${ }^{20}$ Inleidinge, 3.32.11.

${ }^{21}$ Inleidinge, 3.32.18.

${ }_{22}$ Jansen, Theologie, Philosophie und Jurisprudenz in der spätscholastischen Lehre von der Restitution, 49-78; Sampson, The Historical Foundations of Grotius' Analysis of Delict, 134-5, 151-60.

${ }^{23}$ Sampson, The Historical Foundations of Grotius' Analysis of Delict, 164-169, 230, 237-243.

${ }^{24}$ Inleidinge, 3.38.18.
} 
claim; for Grotius, the onus is on the possessor (A) to restore the property by seeking out its true owner.

Grotius's remedial analysis can be made to parallel that expected by a civilian audience, but behind this is a difficulty that underlies the entirety of Grotius's remedial discussion. The bifurcation of the available remedies into restoration (weder-evening or restitutio) and penalty (poena) resembles somewhat the orthodox civilian classification of actions as reipersecutory or penal. It is clear enough that a penal action (in the traditional civilian sense) and a legally imposed penalty (as described by Grotius) correspond, even if the ambit of punishments that might be imposed by a poena in the sense employed by Grotius is far broader than the purely financial consequences of condemnation in a penal action. However, reipersecution and restoration are not perfect analogues. Reipersecution is focused on a single set of issues: whether the defendant possesses property to which the claimant is entitled, or else has disposed of it in circumstances that evince bad faith. Restoration is focused not just on reipersecution, but also on the inequalities that exist between the parties that can be attributed to the behaviour of the defendant. Consequently, the sense in which it manifests in Grotius's account of liability for wrongdoing is often personal. Although restitutio ratione rei, which more closely resembles the reipersectuory remedies of the civilian tradition, is also present, it can only apply to wrongs involving the deprivation of property. For every other wrong that generates a restorative remedy, from property damage to defamation and even personal injury, Grotius is taking restitutio in a direction that has no reipersecutory analogue in the civilian law tradition.

Although Grotius attempts to make his remedial structure align with civilian expectations, an examination of the doctrinal detail reveals a number of friction points. The first arises in the remediation of wounds. The core duty imposed in cases of such injuries in the Inleidinge is to cover the financial outlay incurred as a result: medical expenses, loss of profits, and other costs. ${ }^{25}$ These are payable not only within the period of treatment, but for as long as the injury carries financial consequences, even if permanent. ${ }^{26}$ This follows the natural law approach closely. ${ }^{27}$ There are, however, two points of departure. The first is a tokenistic effort to assimilate the civilian approach by including some assessment of pain and deformity flowing from the injury. ${ }^{28}$ This is openly recognised as being something different from weder-evening proper, while also a departure from the position in the Digest. ${ }^{29} \mathrm{~A}$ concern for scarring and deformities had become a central feature of the civilian treatment of compensation for injuries, and an accepted deviation from the ancient authorities. ${ }^{30}$ Thus Grotius's inclusion of the same has the hint of reconciliation, tacking on a solution expected

\footnotetext{
${ }^{25}$ Inleidinge, 3.34.2.

${ }^{26}$ Inleidinge, 3.34.2.

${ }^{27}$ DJBAP, 2.17.14.

${ }^{28}$ Inleidinge, 3.34.2.

${ }^{29}$ D.9.1.3 (Gaius), recognised as a point of departure from Roman law by Groenewegen in his commentary on Inleidinge, 3.34.2, ad D.9.3. (l. ult.)

${ }^{30}$ Feenstra, 'Reparation du dommage et prix la douleur chez les auteurs du droit savant, du droit nturel et du droit romano-hollandais' in Durand, Poirier and Royer (eds), La douleur et le droit (1997). For its continued importance in seventeenth-century Roman-Dutch law and beyond, see Van Aswegen, 'Aquilian Liability I (Nineteenth Century)' in Zimmermann and Visser (eds), Southern Cross: Civil Law and Common Law in South Africa (Oxford, 1996), 559 n.1.
} 
by a civilian audience to a primarily restorative remedy which is itself distinct from that offered in the Corpus Juris Civilis.

A more jarring difference arises in relation to the limitation of claims. The duty to make weder-evening arises immediately following the wrong by operation of natural law. ${ }^{31}$ Under natural law the duty to make restitutio was perpetual, staining the conscience of the wrongdoer until fulfilled. ${ }^{32}$ This would not always be the case in local law. Grotius reports a custom in Voorn stemming from a statute of 1519 that compelled injured parties to report the fact of injury to a judge or similar official within three days of the injury, or else forfeit their right to pursue a remedy. ${ }^{33}$ The incentivisation of speedy redress accords with the goals of the natural law remedy, but its outright limitation within such a narrow timeframe is difficult to reconcile with it. In fact, Grotius makes no effort to reconcile: the custom in Voorn is noted as a legislative fact that cannot be navigated around. It is not said to extend any further than Voorn, but its existence cannot be circumvented. On this point, the result is necessarily pluralistic: one solution for Voorn, another for the remainder of Holland. This stands in stark contrast to the largely unitary nature of the most of his account of liability for wrongdoing.

Similarly difficult to reconcile, but more general in operation, are the various provisions relating to damage caused by ships. Here the degree of compensation payable differs according to the degree of fault. Where a vessel adrift causes damage without fault, the obligation that arises is to pay compensation of just half the damage caused (whereas the presence of fault results in an obligation to restore in full). ${ }^{34}$ This rule was laid down in a placaat of King Charles in 1551, and so again represents an unavoidable instance of specific liability that does not obviously fit within the natural law superstructure. Damage caused by vessels, an area of obvious prior importance within the law of Holland, emerges as a sui generis delictual regime ancillary to the core of Grotius's treatment of wrongdoing.

Across these examples it is possible to see differing approaches to reconciliation. The custom of Voorn and the enactments in relation to collisions are simply immovable obstacles to fully integrating their subject matters with the natural law framework by virtue of their legislative footing. They stand out as anomalies, but anomalies that it is beyond Grotius's power to circumvent. Elsewhere Grotius has more latitude for reconciliation. It seems generally successful in the case of personal injury, where the natural law framework is slightly distorted to fit contemporary civilian expectations. The inclusion of a remedy for scarring and deformity is not an issue considered in any detail by the Thomists in that context, but it is not unduly distortive to think of a remedy for such harms as 'restorative' given the Thomists' discussion of how such injuries might affect marriage prospects. ${ }^{35}$ However, Grotius's attempt at aligning his own remedies with the traditional classification of actions reveals a fundamental incompatibility between the two frameworks, and it is an incompatibility that can only be addressed through focusing his discussion on scenarios (such as the deprivation of property) where the civilian and natural law frameworks are ad idem.

\footnotetext{
${ }^{31}$ Inleidinge, 3.32.16.

${ }^{32}$ This is not a point directly made by Grotius. It is, however, a staple from Aquinas onwards in the texts that clearly provide the basis for Grotius's view of restoration: ST, II-II, q.62.a.8.

${ }^{33}$ Van Waesberge, Keuren ende privilegien des Lands ende Heerlijckheyts van Voorne (Rotterdam, 1717), 113

(Article CXVIII).

${ }^{34}$ Inleidinge, 3.37.7.

${ }^{35}$ Jansen, Theologie, Philosophie und Jurisprudenz, 100-106.
} 


\section{Section 2 - Wrongs, Rights and Taxonomical Difficulties}

The same incompatibility arises when considering the range of wrongdoing covered by the Inleidinge relative to Grotius's natural law work. Perhaps the starkest difference between Grotius's natural and local accounts of liability for wrongdoing is taxonomical: his Inleidinge includes a category of obligations omitted entirely from De Jure Belli ac Pacis, namely obligations quasi ex maleficio. The rationale offered is pragmatic. Delictual obligations ought to arise from wrongdoing, with the core notion of maleficium providing the justificatory force for the imposition of liability. ${ }^{36}$ This aligns with the typical portrayal of delictual responsibility as arising from personal fault. Natural law is said to look to the truth of the act, and so only imposes liability where responsibility is proven. ${ }^{37}$ In local law, however, difficulties of proof can arise, and so the category of obligations quasi ex maleficio arise to deal with wrongs for which it is not necessary to prove guilt. ${ }^{38}$ Thus this is a category of obligation that presumes fault, rather than dispenses with it as is sometimes presumed to be the case with categories modelled on the Roman obligations quasi ex delicto. ${ }^{39}$

This rationale translates imperfectly to the substance of Grotius's treatment of obligations quasi ex maleficio. Instances of strict liability are to be found, such as the case of the wagoner who allows his horses to bolt, thereby causing injury. ${ }^{40}$ Although the text expressly states that liability is imposed regardless of fault, a parallel is drawn in Groenewegen's notes between this case and D.9.2.8.1, which deals with an analogous scenario wherein the question of fault is dealt with in terms of imperitia, or unfitness for the task undertaken. Although plausible, it is not obvious that this is how Grotius intended to deal with the case. A further example of strict liability is to be found where a ship adrift crashes into another ship in such a way as to cause damage. Here again the obligation arises even without fault on the part of the defendant, and there is no attempt by Groenewegen to introduce fault by a Roman analogy. ${ }^{41}$ Instead the scenario is linked to the placaat of 1551. The problem facing Grotius appears to be the assimilation of the existing regime of wrongs within his natural law framework. The absence of fault means this cannot be an obligation ex maleficio, and so by default it needs to be quasi ex maleficio. It does not clearly conform to the rationale for obligations of this type offered by Grotius - it is not that fault does not need to be proven, but rather that fault is not relevant at all to this particular instance of liability. Obligations quasi ex maleficio thus become a residual pool of obligations associated with wrongdoing and harm, obscuring the conceptual clarity that Grotius tries to entrench in his taxonomy of obligations.

Further taxonomical difficulties stem from the realignment of existing delictual structures to fit the natural law ordering laid down in De Jure Belli ac Pacis. Like that work, the Inleidinge's treatment of wrongdoing is dealt with through a general introduction followed by a series of generic wrongs grouped by harmed interest: wrongs to life, wrongs to

\footnotetext{
${ }^{36}$ Inleidinge, 3.32 .3 .

${ }^{37}$ Inleidinge, 3.32.22.

${ }^{38}$ Inleidinge, 3.32.22.

${ }^{39}$ E.g. Stein, 'The nature of quasi-delictal obligations in Roman law' (1958) 5 RIDA 563, Gordon, 'The Roman class of quasi delicts' (1967) 21 TEMIS 303.

${ }^{40}$ Inleidinge, 3.38.12.

${ }^{41}$ Inleidinge, 3.38.17.
} 
the person, wrongs to freedom, wrongs to honour, wrongs to property, and finally obligations quasi ex maleficio. ${ }^{42}$ Within each of these categories some allusion is made to specific forms each wrong might take, but the emphasis is overwhelmingly general. Take, for instance, wrongs to life. It is recognised that a great many factors might influence how we think of a homicide: was it a crime of passion, the product of personal rivalry, or complete neglect? Did the victim have a fighting chance, whether through being armed himself, or being attacked openly rather than being ambushed $?^{43}$ All of these factors, Grotius argues, have no bearing on the underlying analytical structure of the wrong. If a life is wrongfully taken, the obligations to restore and to suffer a penalty arise. These factors affect only the severity of the penalty, not the fundamental nature of the wrong, and have no bearing whatsoever on the obligation to restore. Specific wrongs feature as illustrations of a genus, rather than as species. ${ }^{44}$ In this respect there is a strong resemblance to the structure of De Jure Belli ac Pacis. ${ }^{45}$

Within this structure it was necessary for Grotius to accommodate two distinct bodies of legal authority alongside his own brand of natural law doctrine: the nominate wrongs of Roman law, as modified in the later civil law tradition, and the various wrongs unique to Holland created by legislation. Both of these needed to be assimilated, and their necessarily instantiated nature reconciled with the more general focus of Grotius's project. Without this, the Inleidinge would be little more than a work of high theory, an exposition of what the law might be made to look like but alien to the legal realities of its readership. The difficulty lies in the patchwork nature of wrongs that have emerged over time in response to particular social pressures. Grotius's own project is the product of one mind, with standardisation across the gamut of wrongdoing: the same approach to fault, the same approach to remediation, and so on. But this was not how the civil law had traditionally approached delict, and the assimilation of these two streams of delictual doctrine into Grotius' natural law was consequently uneven.

Obligations ex maleficio are divided into five categories, organised by the right infringed by the wrongdoer: life, person, freedom, honour, property. The Roman approach to delict is concentrated on the last of these, with three of the four institutional delicts (furtum, rapina and damnum iniuria) focusing on depravation of and damage to property. This is reflected in Grotius's treatment of wrongs to property, which is divided into three types of injurious action: destruction (goed-verderving), deprivation (goed-beneming) and damage (goed-verargering). ${ }^{46}$ Within these three wrongs a variety of Roman delicts find new homes, although some (particularly liability under the lex Aquilia) are made to straddle multiple wrongs. Destruction appears to be the most serious of the three, dealing with damage caused by fire and inundation alongside the killing of cattle. ${ }^{47}$ While the killing of cattle is an obvious reference to the first chapter of the lex Aquilia, the specificity of fire and inundation

\footnotetext{
42 The term translated here (and elsewhere) as freedom is actiones propriae. Contractual autonomy might be a more apt description of its content: it relates to the ability to make free decisions for oneself.

${ }^{43}$ Inleidinge, 3.33.5.

${ }^{44}$ See also Inleidinge, 3.34.1, 3.35.1.

${ }^{45}$ Sampson, The Historical Foundations of Grotius' Analysis of Delict, 17-24.

46 The terminology is taken from Lee's translation of the Inleidinge.

${ }^{47}$ Inleidinge, 3.37.2. The final clause ('die eens ander beeste dooden ende diergelijcken') makes it clear this applies to more than just cattle, though whether it applied to all animals or just those 'comparable' (diergelijcken) to cattle is unclear.
} 
is curious. ${ }^{48}$ The language of burning is found in chapter three of the lex Aquilia, but is not obviously associated with killing cattle, and inundation as a means of causing property damage is not discussed in Roman law. The wrong as a whole appears to be concerned with the total destruction of property: killing certain animals, and particularly catastrophic methods of damaging inanimate property. ${ }^{49}$ As the obligation to restore scales with the degree of damage - if property is completely destroyed, then the obligation to restore is simply to account for the full value of the thing - there is no obvious reason for the identification of a specific wrong of destruction other than to show where a particular civilian wrong - chapter one of the lex Aquilia - fits into Grotius's scheme.

The other two wrongs are more straightforward. Deprivation, as the name suggests, maps primarily onto furtum and rapina, but is also a vehicle for a number of smaller civilian wrongs: the lex Cornelia de falsis appears as the use of fraudulent means (e.g. forgeries) to deprive another of their property and the interdicts de vi et vi armata appear in a distinction between robbers and brigands. ${ }^{50}$ More curious is the inclusion within deprivation of wounds to animals, more obviously a case of damage to property. Presumably the focus on animate property shows that Grotius views this not as damage in the ordinary sense, but depriving the owner of the use of the animal, making it a more natural fit for deprivation than damage. The final wrong, damage, appears residual in nature, covering any improper alteration of another's property. ${ }^{51}$ Chapter three of the lex Aquilia, covering any and all property damage not covered by the first chapter, straddles the two wrongs. This maps onto the two distinct senses in which corrumpere, the harm verb of chapter three, came to be understood in Roman law. It referred both to damaging property and to making it worse, as in servi corrupti (causing the moral deterioration of a slave), in much the same way as the term is used today when describing 'spoiling' a child or an appetite. The former is Grotius's second wrong to property, the latter his third. This degree of instantiation is unnecessary. The residual wrong, deprivation, could have covered all three species of property wrongdoing. There is no difference in the obligation to restore as between the wrongs, and no difference in penalty is envisaged. It has the sense of a compromise, drawing out the different ways in which property can be harmed that had come to be expected by a civilian audience.

Alongside these three core property wrongs, two further specific wrongs relating to particular patterns of harmful conduct are discussed: misfeasance by officials and damaged caused through ships crashing. ${ }^{52}$ The latter, discussed above in relation to remediation, is the product of local legislation, and must be dealt with independently of ordinary property damage due to the unique provisions determining the availability and scope of a remedy. ${ }^{53}$ The local description of these wrongs is simply too specific to be assimilated with the generalised form of destruction, deprivation and damage. Official misfeasance is

\footnotetext{
${ }^{48}$ Although chapter one of the lex Aquilia also dealt with the killing of slaves, liability as it relates to slaves is a topic expunged from Grotius's natural and local law analyses.

${ }^{49}$ Furthermore fire as a specific form of wrongdoing resurfaces as the first form of obligation quasi ex maleficio. This simply reflects the dangerousness of fire: even if it cannot be proven that a fire was culpably allowed to spread, the obligation quasi ex maleficio generates a duty to restore. The specific mention of inundation likely reflects the long history of regulating waterways in the Netherlands via waterschappe and the catastrophic risk of flooding in a country with a significant landmass below sea level.

${ }^{50}$ Inleidinge, 3.37.3.

${ }^{51}$ Inleidinge, 3.37.4.

${ }^{52}$ Inleidinge, 3.37.7-9.

${ }^{53}$ E.g. the possibility of only half damages in 3.37.7, and the back-and-forth nature of proceedings in 3.37.8.
} 
authentically civilian but deals with pure economic loss in a way that the three primary property wrongs do not. ${ }^{54}$

If Grotius found it difficult to encompass the full range of property wrongs covered by civilian jurists within a single category, the delict of iniuria gave him the opposite problem. The Roman iniuria had at its heart the notion of contumelia or disrespect, but such could be manifested in many ways, from harassment through physical violence to defamatory conduct. ${ }^{55}$ This scope caused it to take on an almost residual character in the writings of the commentators, with Donellus using it for essentially any civil wrong recognised by the law that didn't affect property, life or limb. ${ }^{56}$ This scope meant that it did not obviously have at its heart the violation of a particular interest. As a result, Grotius divided the civilian delict across two distinct types of wrongdoing: wrongs to freedom and wrongs to honour. That these are two distinct species of wrongdoing is a point dealt with in De Jure Belli ac Pacis, which dealt separately with wrongs affecting freedom (actiones propriae) and honour (though singular in the Inleidinge, in natural law it is divided into fama and honor). ${ }^{57}$

Both wrongs to freedom and wrongs to honour are modelled closely on the civilian actio iniuriarum, while also incorporating the remedial adaptations made to restitutio for wrongs of this type in De Jure Belli ac Pacis. The restorative element of the remedy is satisfied by public acknowledgement of the defendant's wrongdoing and a request for forgiveness. ${ }^{58}$ Where a person's reputation if falsely impugned, the remedy is slightly more involved: in addition to the public acknowledgement of fault and request for forgiveness, the defendant must also publicly declare that the defamation was untrue, and publicly extoll the virtues of the wronged party. ${ }^{59}$ If the defamation was true, then the defendant needs simply to publicly declare that he revealed it in a wrongful manner. Alongside this variation of wederevening, a 'quasi-penalty' modelled on the actio iniuriarum is payable. Like the actio iniurarum, the quasi-penalty is neither actively nor passively transmissible, and its pursuit is lost both by a year's silence or any mark of friendship between the parties. ${ }^{60}$ On the last point Grotius cannot give a single position due to existing variation between provinces in whether the limitation period affects wrongs to honour through physical injuries, a further example of the impediments caused by existing practices to harmonisation via natural law.

As in De Jure Belli ac Pacis, wrongs to honour deal essentially with defamation, and in a broadly consonant manner. However, wrongs to freedom differ significantly from their natural law incarnation. In De Jure Belli ac Pacis wrongs affecting freedom of action (in that context actiones propriae) deal essentially with contractual misfeasance: the use of fraud and

\footnotetext{
${ }^{54}$ Inleidinge, 3.37.9.

${ }^{55}$ Daube, 'Ne quid infamandi causa fiat: The Roman Law of Defamation' in G Moschetti (ed), Atti del Congresso Internazionale di Diritto Romano e di Storia del Diritto (Giuffrè 1951) vol.3, 413; Birks, 'Infamandi causa facta in disguise?' [1976] Acta Juridica 83; Ibbetson, 'Iniuria, Roman and English' in Descheemaeker \& Scott (eds), Iniuria and the Common Law (Hart, 2013).

${ }^{56}$ Donellus, Commentariorum de Jure Civili, 15.25 .2 (on iniuria).

${ }^{57}$ In the Inleidinge Grotius defines honour as reputation within society. This maps onto the fama of his natural law. The distinction between honor and fama as interests affected by wrongdoing is thomist. Honor refers to an introspective value, the sense of our own virtue we carry, of particularly importance within an Aristotelian moral framework. Fama is how others perceive us, or reputation. It is not surprising that honor - an essentially moral concept - slips out of Grotius's formulation of positive law.

${ }^{58}$ Inleidinge, 3.35.2, 3.36.3.

${ }^{59}$ Inleidinge, 3.36.3, DJBAP, 2.17.22.

${ }^{60}$ Inleidinge, 3.35.3-5.
} 
coercion to procure agreement, thereby denying the victim of contractual autonomy. ${ }^{61}$ Such is absent from the wrongs to freedom of the Inleidinge. Instead, the only specific wrongs enumerated under this heading are instances of sexual misconduct: rape, 'copulation by consent' and adultery. ${ }^{62}$ Sexual wrongs are entirely absent from De Jure Belli ac Pacis. Grotius explains the absence of the second wrong, fornication, from the concerns of natural law through the maxim (itself attributed to natural law) volenti non fit iniuria. ${ }^{63}$ While this could conceivably explain why adultery is not discussed, it does not solve the mystery of the omission of rape in De Jure Belli ac Pacis. ${ }^{64}$

Viewing the approach to wrongdoing in the Inleidinge taxonomically, it is apparent that many of the issues that affected Grotius's discussion of remediation also influence the overall scope of liability through the enumeration of wrongs. The core concern appears to have been to house the disparate wrongs expected by a civilian audience, while still committing to as an overall structure built upon the infringement of rights and the avoidance of focusing on particular patterns of behaviour. To this end, the concept of freedom as a protected interest is recast from its natural law counterpart, and heavy work is made of the civilian iniuria which, through its bifurcation, is used to substantiate two protected interests (reputation and freedom) which had received relatively little attention from contemporary civilians. Here the overarching project of reconciliation appears to have been more successful. The impediment, however, comes once again from the existence of anomalous wrongs created by specific enactments. To deal with these Grotius creates a new category of obligation, quasi ex maleficio. Though this is likely as elegant a solution as could be adopted given the need for reconciliation, it is a conscious departure from both the shape and the justificatory rationale of the natural law conception of liability for wrongdoing.

\section{Section 3 - The Limits of Personal Responsibility}

Grotius places personal responsibility at the heart of delictual liability in both natural and local law. This is at its clearest in the Inleidinge in Grotius's account of capacity. The possession of one's mental faculties is all that is needed for liability. ${ }^{65}$ Even minors can be held liable (at least to make weder-evening, though perhaps not to suffer a penalty) so long as they possess this de minimis capacity. ${ }^{66}$ The degree of fault required for liability is a topic that Grotius does not explore, even if it is of central concern to contemporaries even in the natural law mould. ${ }^{67}$ The necessity of fault is taken for granted. It does not receive a dedicated treatment, instead cropping up in the Inleidinge tangentially. An example of this is to be found in the distinctions that might be thought to apply under the umbrella of

\footnotetext{
${ }^{61}$ DJBAP, 2.17.17.

${ }^{62}$ Inleidinge, 3.35.7-9.

${ }^{63}$ Inleidinge, 3.35.8. Th

${ }^{64}$ It may be that sexual wrongdoing is viewed by Grotius's thomist influences as a wrong associated not with (in)justice, as are all other wrongs that give rise to liability, but a wrong associated with lust and temperance. See further Sampson, The Historical Foundations of Grotius' Analysis of Delict, 200-205.

${ }^{65}$ Inleidinge, 3.32.19.

${ }^{66}$ Inleidinge, 3.32.19

${ }^{67}$ E.g. Voet, ad D.9.2, points 13-24. Within the Thomist tradition, fault received an elaborate analysis drawing heavily on civilian accounts of culpa (a term significant to delict due to its inclusion in juristic interpretation of the lex Aquilia, although it received its fullest civilian analysis in relation to contract), e.g. Navarrus, Enchiridion, 17.177, Lessius, De Iustitia et Iure, 2.7.6.
} 
homicide. ${ }^{68}$ Dealing with the manifold factors that might be thought to be relevant to the division of homicide into discrete offences, Grotius brushes them aside: 'as regards compensation (weder-evening) these distinctions are not considered, since it is enough for this purpose that the death was caused by someone's fault'. For Grotius, the proposition that fault is an indispensable criterion for liability goes without saying.

In the absence of a dedicated treatment of fault, its character needs to be abstracted from the scraps of text in which it is touched upon. Fault is given its most detailed treatment in relation to wrongs against life and the person. Here it has a strongly civilian flavour, mapping onto the contemporary analysis of dolus and culpa. The text quoted above on distinctions within homicide continues '.. in which is included the neglect or unskilfulness of a physician, or midwife; and the neglect or ignorance of a wagoner or skipper, or the incapacity of either in managing a ship or horses' ${ }^{69}$ This is little more than a list of some of the leading culpa texts in the Digest title on damnum iniuria. ${ }^{70}$ The example that stands out is the skipper's inability to manage his ship which, though it has precedent in the Digest, is elevated to a core case given the specific concern of local rules for wrongs involving ships. ${ }^{71}$ Culpability is approached negatively, using a twist on the classic civilian text si putator (D.9.2.31) to describe when people are not to be considered culpable. ${ }^{72}$ Moreover, Grotius's account of the justifiability of killing and wounding is lifted from the description of iniuria in D.9.2, covering the killing of thieves caught in the night, adulterers, rapists, and in defence of oneself, one's wife, children or property. ${ }^{73}$ Entirely consonant with prevailing civilian doctrine, Grotius's core account of fault is orthodox and so receives little elaboration.

The orthodox focus on personal responsibility analysed in terms of dolus and culpa finds a further form of expression that is taken from outside the civilian tradition: liability as an accessory. In the Corpus Juris Civilis liability other than as the principal wrongdoer is analysed in rather narrow terms using the language of ope et consilio. This narrowness is reflected in the restrictive formulation of liability as an accessory to a homicide in the Inleidinge. ${ }^{74}$ However, in the overarching description of liability for wrongdoing Grotius offers a more comprehensive account of the various species of accessorial liability. ${ }^{75} \mathrm{His}$ analysis is divided between those who 'actually occasion' and those who 'passively occasion' the wrong. The former has six variants: command, consent, standing by, abetting, advising and recommending. ${ }^{76}$ This correlates closely to his account of the same topic in natural law, and is taken directly from thomist sources. ${ }^{77}$ Passive contributions invoke the language of duty, and again correlates closely to a common example in theological texts. Both of these forms of accessorial liability are comprehensively dealt with in the juridified thomist treatises of the sixteenth and seventeenth centuries. ${ }^{78}$ Even though this analysis of accessorial liability has a distinctly thomist flavour, the specific instances enumerated are compatible with

\footnotetext{
${ }^{68}$ Inleidinge, 3.33.5.

${ }^{69}$ Inleidinge, 3.35.5.

${ }^{70}$ Physicians: D.9.2.8.pr; midwives: D.9.2.9.pr; wagoners: D.9.2.8.1.

${ }^{71}$ D.9.2.29.2.

72 Inleidinge, 3.33.8.

${ }^{73}$ Inleidinge, 3.33.9. D.9.2.4.pr-5.1.

${ }^{74}$ Inleidinge, 3.33.4.

${ }^{75}$ Inleidinge, 3.32.12-14.

${ }^{76}$ Inleidinge, 3.32.13.

${ }^{77}$ DJBAP, 2.17.6-9; ST, II-II, q.62.a.7 provided the foundation for a Thomist analysis of participation.

${ }^{78}$ E.g. Soto, De Iustitia et Iure, 4.7.3; Navarrus, Enchiridion, 17.17; Lessius, De Iustitia et Iure, 2.13.2.
} 
civilian learning. Across the Digest individual texts can be found that represent each of the individual forms of complicity. ${ }^{79}$ What the civilian tradition lacks is the systematic analysis found in Thomism and, under that influence, Grotius. ${ }^{80}$ Thus this is an area where Grotius could easily introduce a strand of his natural law as a systematising force, imposing conceptual order on existing civilian learning. The result is a further articulation of the centrality of personal responsibility, not just for harm directly caused but for harm which the defendant indirectly brings about.

There are, however, two areas where Grotius's central focus on personal responsibility is challenged by existing local rules: passive transmissibility, and liability for harm caused by another. Passive transmissibility describes the responsibility of the defendant's heir to comply with the obligation that bound his predecessor. For a civilian, the expectation would be that penal actions are not passively transmissible, while reipersecutory actions are. Grotius writes that the heir is not bound to suffer the penalty that would have been inflicted on the wrongdoer (unless joinder of issue had already occurred), but is compelled to make weder-evening 'so far as lies in their power'. ${ }^{81}$ This appears to be an attempt at treating his penal and restorative obligations as parallel to traditional penal and reipersecutory actions. Suppose X stole a book from Y before dying. X's heir, Z inherits the book alongside the rest of the estate. The penal actio furti does not lie against $Z$ as there is no delictual obligation extant between $\mathrm{Y}$ and $\mathrm{Z}$ - the latter has simply not wronged the former. But the reipersecutory vindicatio for the book lies against $Z$ for the simple reason that he possesses property that is rightfully Y's. The logic is stretched slightly by the reipersecutory condictio, which is predicated on the idea that Z's pool of assets that he has inherited from X has been enhanced by the theft, with the question of whether the condictio furtiva could lie against the unenriched heir forming a testcase for civilians.

The parallel between the actio furti and Grotius's penalty for theft (whatever that might be in local law) is convincing, but as discussed above weder-evening does not conform to a civilian reipersecutory action. ${ }^{82}$ Although it does have a proprietary form in restutitio ratione rei, this form is subordinated to the dominant form of the restorative remedy in relation to liability for wrongdoing: a personal obligation to correct the imbalance unjustly caused (restitutio ratione acceptionis). This form of restitutio applies beyond cases of theft to every wrong recognised within a legal system: to restore a damaged reputation, to restore the financial gap caused by injury or death, to repair damaged property, and so on. In short, its scope far exceeds that of the vindicatio-paralleling restitutio ratione rei. While there is a clear logic behind allowing a vindicatory claim against an heir, insofar as he is enriched by his inheritance of stolen property, the imposition of an obligation on the heir to make wederevening on account of wrongfully causing loss in the form of an injured reputation or bodily harm is a very poor fit for Grotius's broader analysis of wrongdoing. Given his emphasis on personal responsibility, the imposition of onerous personal liability on an innocent heir is anomalous. The reservation that the obligation against the heir lies 'so far as lies in their

\footnotetext{
${ }^{79}$ Groenewegen suggests the following: command - D.9.2.37; consent - D.9.2.14 and generic reference to D.43.16; standing by - generic reference to D.47.16; abetting - D.47.2.54.3; advising - D.50.17.47.pr; recommending - D.47.10.11.6.

${ }^{80}$ For instance, Soto provides the unifying rationale for accessorial responsibility that 'anyone who is the cause of an unjust taking is held to make restitutio by reason of that taking' - Soto, De Iustitia et Iure, 4.7.3.

${ }^{81}$ Inleidinge, 3.32.10.

${ }^{82}$ Above, p.5.
} 
power' shows Grotius's own recognition of this. ${ }^{83}$ It is a forced attempt at mapping the natural law framework onto the existing framework of remedies, with the misalignment between weder-evening and reipersecution causing a significant departure from the demands of natural law.

The second friction point between Grotius's natural law approach to wrongdoing and prevailing local law concerns instances wherein a defendant can be held liable for harm caused by another. Three basic fact patterns are discussed: harm caused by animals, by ships ${ }^{84}$ and by servants. The divergence between local law and natural law was in fact flagged by Grotius in De Jure Belli ac Pacis:

It should also be noted that under the civil law an owner is not liable for loss caused by his slave or animal. For the master, who is not at fault, is not bound by the law of nature; neither is he whose ship, without his fault, collides with another's ship causing loss, although under the laws of many systems, including our own, the loss is divided between them owing to the difficulties of proving fault. ${ }^{85}$

With each of these three cases, the divergence between natural and local law is caused by an inability to manoeuvre around local legislation. ${ }^{86}$ Instead, the incongruence between these heads of liability and the primacy of fault in maleficium proper is addressed at a taxonomical level. Liability for wrongs committed by animals, ships and servants are addressed under the heading of obligations quasi ex maleficio. The boundary between the two categories of obligation is inconsistently articulated in the Inleidinge. When introducing the category in his general overview of maleficium, he wrote:

But, above all, it is necessary to observe that natural law looks only to the truth of the act; but municipal law, seeing that some injuries even, when they take place, do not easily admit of proof, has in some cases introduced an obligation as if the same was occasioned by injury. ${ }^{87}$

The boundary between maleficium and quasi maleficium is therefore initially presented as one of proof. There is a wrong - and thus fault - behind both types of obligation, but the need to prove it is elided in the case of quasi maleficium, essentially a species of res ipsa loquitur. But upon turning his treatment to these obligations in detail, he begins with a different justification:

Quasi ex maleficio is when the law imputes any event to a delict: this can take place where there is in truth no actual delict, but nevertheless not without lawful cause; as, when a person is injured from or by anything of ours. ${ }^{88}$

\footnotetext{
${ }^{83}$ Inleidinge, 3.32.10.

${ }^{84}$ Grotius' discussion of ships here is distinct from his earlier discussion in 3.37 .8 of wrongs to property caused by ships, in that context a 'full' instance of maleficium rather than, as here, giving rise to an obligation quasi ex maleficio.

${ }^{85}$ DJBAP, 2.17.21.

${ }^{86}$ See Groenwegen's notes at 3.38.11(on animals) and 3.38.16-18 (on ships). In relation to animals, he refers to charters enacted between 1403 and 1606. The 1403 charter is likely Handvesten, privilegien, handelingen costuymen ende willekeuren der Stadt Amsterdam (Amsterdam 1624), 16-17. On ships, he refers to a decision of the High Court of Holland alongside a range of local enactments.

${ }^{87}$ Inleidinge, 3.32.22.

${ }^{88}$ Inleidinge, 3.38.1.
} 
The focus now is on where an obligation arises even where there is no delict, and so no fault. The pretence that fault justifies this category of obligation even if it cannot be proven has disappeared. This recourse to a quasi category of liability neatly provides a method of preserving the primacy of fault within maleficium while incorporating the extant heads of liability that the readership would expect to see covered. It is, however, a concession to local law and a dilution of natural law, involving as it does the creation of a source of obligation that exists outside the natural law paradigm. And this concession is only required to find a means of assimilating the sources of obligations already recognised in local law which, owing to their legislative footings, could not simply be ignored.

\section{Conclusion}

Grotius's account of liability for wrongdoing in the Inleidinge is an attempt at reconciliation. In it, perhaps more clearly than in other areas of private law within the treatise, the positive law of Holland is slotted into a framework that bears a striking similarity to his natural law account of the same topic. The subject is rearticulated in a form and language alien to prior civilian expositions of private law. It is, however, a compromised work. In pursuing reconciliation Grotius was stymied by incompatibility at a conceptual level. While his theory of natural law favours generalised wrongs focused on the infringement of rights, a focus on personal responsibility and a directly restorative remedy, the piecemeal wrongs recognised in contemporary local and learned law pulled in different directions, lacking as they did any single theoretical architect. Where possible, Grotius attempts to rearticulate local law in a manner consonant with his natural law ideal. However, the greatest impediment to this is entrenched legislation, whether dealing with personal injuries in Voorne or liability for ship collisions. In these instances, the legislative enactments jut awkwardly out from the natural law edifice, a reminder of the compromises suffered in the process of the Inleidinge's composition. 